Vol. 5, No. 2, 2020

\title{
DETERMINATION OF SIGNIFICANT FACTORS OF LANDSLIDE PROCESSES AND FLOODING
}

\author{
Mykhailo Katkov $^{1}$, Myroslav Malovanyy ${ }^{2}$, Iryna Kotsiuba $^{3}$, Tetyana Senchuk ${ }^{1}$, Maryna Lavinda ${ }^{1}$ \\ ${ }^{1}$ Kharkiv National University of Urban Economy named after O. M. Beketov, \\ 17, Marshala Bazhanova Str., Kharkiv, 61002, Ukraine, \\ ${ }^{2}$ Lviv Polytechnic National University, \\ 12, S. Bandery Str., Lviv, 79013, Ukraine, \\ ${ }^{3}$ Zhytomyr Polytechnic State University, \\ 103, Chudnivska Str., Zhytomyr, 10005, Ukraine \\ mvkatkov@gmail.com,tanyusha2883@gmail.com, \\ marinalavanda000@gmail.com_chaszmin30@gmail.com
}

https://doi.org/10.23939/ep2020.02.088

Received: 08.04.2020

(C) Katkov M., Malovanyy M., Kotsiuba I., Senchuk T., Lavinda M., 2020

\begin{abstract}
The linear dependence of some geological (significant) factors responsible for landslide and flooding processes on the cost of geotechnical surveys determining these factors was proved. The principle of selection of engineering-geological surveys, which assess the factors of occurrence of landslide and flooding with high probability, was developed. The possibility of identifying economic territories that may be susceptible to landslide and flooding processes based on already existing basic data of previously conducted engineering-geological surveys is substantiated. A preproject (planned) method of calculating the costs of geotechnical surveys based on the existing basic data is proposed.
\end{abstract}

Key words: landslides, floods, significance of factors, linear regression dependence, geological engineering surveys, cost.

\section{Introduction}

Modern economic development has led to a growing shortage of territories for the secure placement of industrial and civilian facilities [1]. This situation forces the exploration of areas where there is a possibility of dangerous geological and hydro-geological processes such as landslides and floods. The possibility of their occurrence and development is enhanced in previously safe territories as a result of excessive and sometimes uncontrolled, illiterate economic activity [2-3]. It should also be noted that there is an increasing trend in the number of such events and an increase in their socioeconomic disadvantage [4-6]. These circumstances require constant, rapid, and low-cost geotechnical surveys to solve a complex of issues that take into account the geological and hydro-geological conditions of the used and perspective territories [7-10]. The data of the proposed studies are devoted to the development of this topical area.

\section{Literature data analysis and problem statement}

Currently, there is a steady increase in geological and hydro-geological emergencies related to landslides and flooding processes. Their consequences are characterized by a high level of material damage $[6,11-$ 13]. There remains the necessity of selection of areas for housing development, construction of public centers, industrial and transport facilities, and mass recreation centers with the least possible risk of occurrence and development of such processes. Information on the geological and hydrological nature is also constantly needed to identify the areas of high risk and to implement their engineering protection.

Assessment of the possibility of landslide and flooding processes requires a large complex of geotechnical survey, which partially or completely includes the following types of work characterized by their long-term duration and high material costs:

- collecting and processing of materials of tests and studies of the past years;

- decryption of aerospace materials; 
- reconnaissance survey with route observations;

- geotechnical survey;

- excavation of geotechnical workings with their testing;

- geophysical exploration;

- field studies of soils;

- hydro-geological studies;

- laboratory studies of groundwater and soil samples;

- desk processing of materials;

- seismic microzoning;

- local monitoring [14-17].

The data of these surveys make it possible to establish with great confidence the factors of the occurrence of landslide and flooding processes and outline engineering measures to prevent them. [14, 17, 18]. However, the requirements for their implementation are often not fully implemented. This is due to the lack of material and temporary resources as well as with low control on compliance with building standards.

These provisions determine the relevance of work that allows us to determine reliably the economic territories with low costs in which landslide and flooding processes can occur in a short period of time.

\section{The purpose and objectives of the study}

The purpose of the study was to develop a complex of methods that allow us to determine reliably the economic territories in which landslide and flooding processes can occur based on already existing basic data with low costs and in a short period of time.

To achieve the goal of the work, the following tasks were set and solved:

1. To prove the linear dependence of some geological (significant) factors responsible for landslide and flooding processes on the cost of geotechnical surveys determining these factors.

2. To develop the principle of selection of geotechnical surveys evaluating the factors of occurrence of landslide and flooding processes with high probability.

3. To substantiate the possibility of identifying economic territories that may be subject to landslide and flooding processes based on the existing basic data of previously performed geotechnical surveys.

4. To offer a pre-design (planned) method of calculating the costs of geotechnical surveys based on the existing basic data.

\section{Materials and methods of studying the significance of a group of factors of landslide and flooding processes formation for mathematical testing of the hypothesis of their linear dependence on the resulting factor}

The main idea of the work is based on testing the hypothesis of the linear dependence of the resulting factor - the cost of geotechnical surveys to eliminate the causes and consequences of landslide and flooding processes on independent variables - selected significant factors of the formation of landslide and flooding processes and determining the group of geotechnical surveys defining these processes.

The objects of the presented research are the economic territories of the Kharkiv region (Ukraine), which are susceptible to landslide and flooding processes. The subject of the research is the relationship between the physical and mechanical properties of soils with the cost of geotechnical surveys.

The methodological basis of the studied regressions is an integrated approach, which includes the analysis of factors that activate landslide and flooding processes, and the selection of factors that correlate with the cost of geotechnical surveys of these factors (the resulting factor) [19].

Assessment of the significance of the group of factors that form landslide processes for the mathematical testing of the hypothesis of their linear dependence on the resulting factor.

Conducting new geotechnical surveys to determine the characteristics of all factors causing landslide processes requires significant material and time costs. At the same time, there are basic data on factors that activate landslide processes in economic territories and data on the cost of these surveys, which are based on previously conducted geotechnical surveys.

According to $[13,14,16,18]$, the following groups of factors that activate landslide processes were analyzed in the work: climatic conditions (precipitation, temperature, barometric pressure, wind), the slope height and steepness indicators, the rock strength indicators, the geological structure, underground water, earthquakes, neotectonics, and vegetation.

As an example, six sites were selected on the territory of the Kharkiv region on which the geological factors of the formation of landslide processes were studied (Fig. 1).

Preliminary analysis of these groups of factors to use them for mathematical analysis made it possible to exclude factors of climatic conditions, due to numerous simultaneous actions; factors of the geological structure, due to the lack of quantitative characteristics; earthquake factor because of the lack of seismic activity in Kharkiv region; neotectonics factor, as the most homogeneous and slow-acting; vegetation factor due to ambiguity of action.

From the remaining groups of factors, for the mathematical evaluation of their significance, factors that have a quantitative digital expression were selected: the level of groundwater, the steepness of the slope, the 
number of plasticity, the total moisture capacity, specific soil adhesion, and strain modulus. Table 1 presents the factors of the formation of landslide processes, which have quantitative digital expression, and the cost of engineering activities to eliminate their causes and consequences.

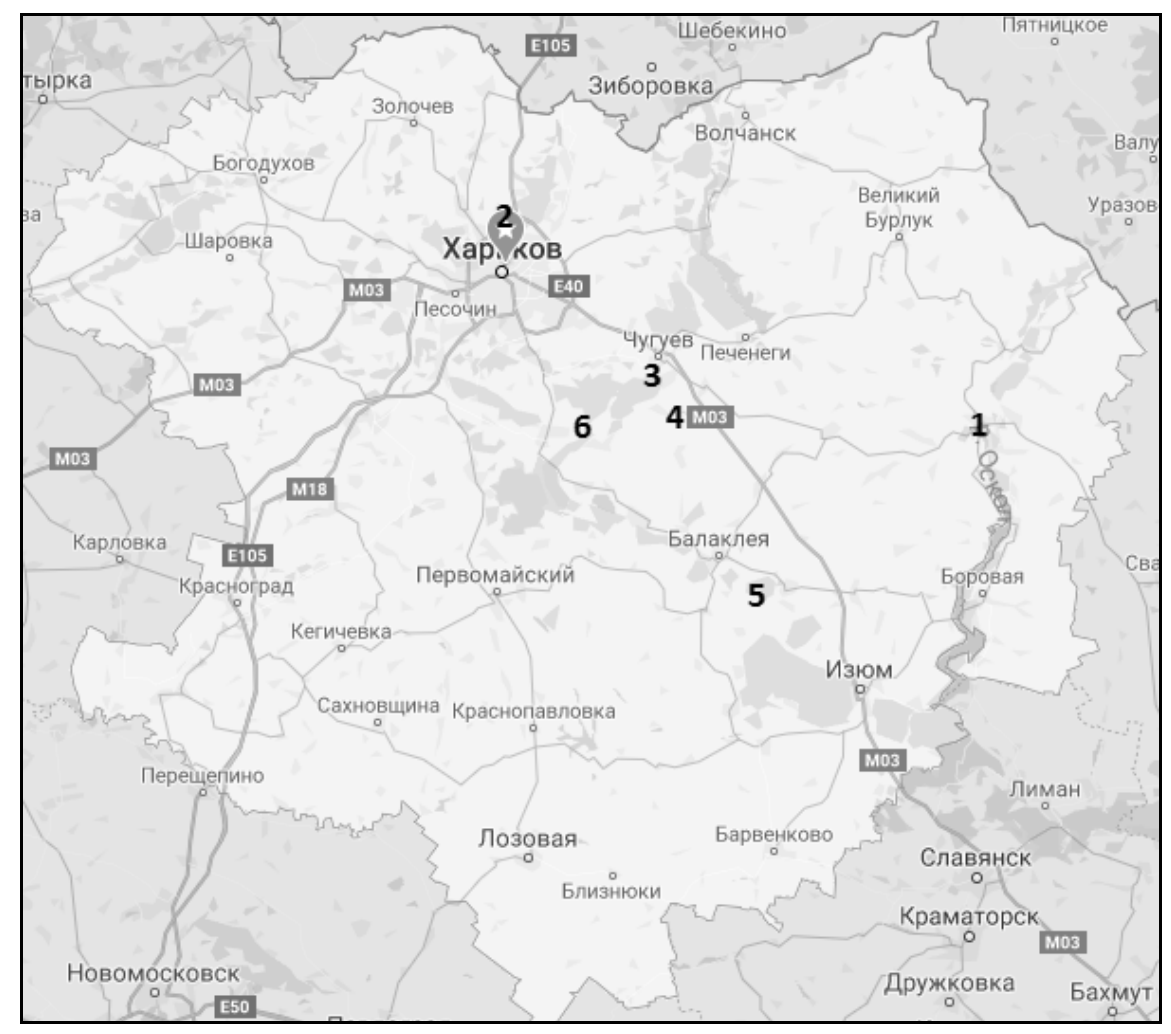

Fig. 1. Overview map of the Kharkiv region (the numbers indicate the areas where the geological factors of the formation of landslide processes were studied):

1 - Kupiansk; 2 - Kharkiv; 3 - Chuhuiv; 4 - v. Kochetok, Chuhuivskyi district; 5 - v. Melove, Balakleiskyi district, 6 - v. Pervomaiske, Zmiivskyi district

Table 1

Factors for the formation of landslide processes and the cost
of geotechnical surveys which determine these factors

\begin{tabular}{|l|c|c|c|c|c|c|}
\hline \multirow{2}{*}{ Factors of formation of landslide processes } & \multicolumn{7}{|c|}{ The number of the study area } \\
\cline { 2 - 8 } & 1 & 2 & 3 & 4 & 5 & 6 \\
\hline Groundwater level, m & 16 & 11.02 & 9 & 11 & 9.01 & 15 \\
\hline Slope steepness, degrees & 27 & 25 & 18 & 12 & 12.03 & 12.02 \\
\hline Number of plasticity & 0.33 & 0.13 & 0.35 & 0.22 & 0.22 & 0.18 \\
\hline Total moisture capacity & 0.42 & 0.25 & 0.39 & 0.33 & 0.35 & 0.28 \\
\hline Specific adhesion, MPa & 9.87 & 17 & 28.09 & 16.4 & 16.2 & - \\
\hline Strain modulus, MPa & 17.17 & 18.91 & 17.97 & 17.43 & 17.52 & 17.69 \\
\hline $\begin{array}{l}\text { The cost of geotechnical surveys determining } \\
\text { these factors, thousand UAH }\end{array}$ & 726 & 750 & 1800 & 105 & 4000 & 2300 \\
\hline
\end{tabular}

The assessment of the significance of these factors, which was performed using the stepwise linear regression method and the estimation of the correlation between the selected individual factors and the resultant factor, determined the group of factors with the highest coefficients of selective correlation: groundwater level, the steepness of the slope and the number of plasticity.
Assessment of the significance of a group of factors of formation of under-flooding processes for mathematical testing of the hypothesis of their linear dependence on the resulting factor.

The necessity of assessing the significance of a group of factors of formation of under-flooding processes for mathematical testing of the hypothesis of 
their linear dependence on the resulting factor and the principle of its carrying out is similar to the operations proposed for the study of landslide processes.

Kharkiv was selected as the object of study, where there are flooded, potentially unsinkable and potentially flooded territories (Fig. 2).

Six sites were investigated on the territory of the city. They have a similar geological structure and consist of their bulk soils, loams, sands, and clays. Flooding of these territories could cause a dangerous emergency, characterized by great economic damage, but based on the data of geotechnical surveys, these events were eliminated [20].

According to $[12,17]$, the following factors that cause flooding were considered in the paper: disordered discharge of rain and meltwater from territories; communication leaks; low throughput of drainage ditches; railway embankments that impede the natural flow of surface water; distance to natural drainage base; filter coefficient (the presence of large areas that have a firm surface and low throughput); intensive multistorey construction; barrage impact of subway tunnels; infiltration by precipitation.

For further analysis, factors that could be adequately statistically processed were selected: leakage from communications, distance from the center of the site to the natural drainage basis, filtration coefficient on the territory, and infiltration supply from precipitation. Among the above factors, the area of flooded territories was added, as the value of engineering measures to prevent flooding depends on its value.

Table 2 presents the factors of flooding and their values and the cost of engineering measures to eliminate their causes and consequences.

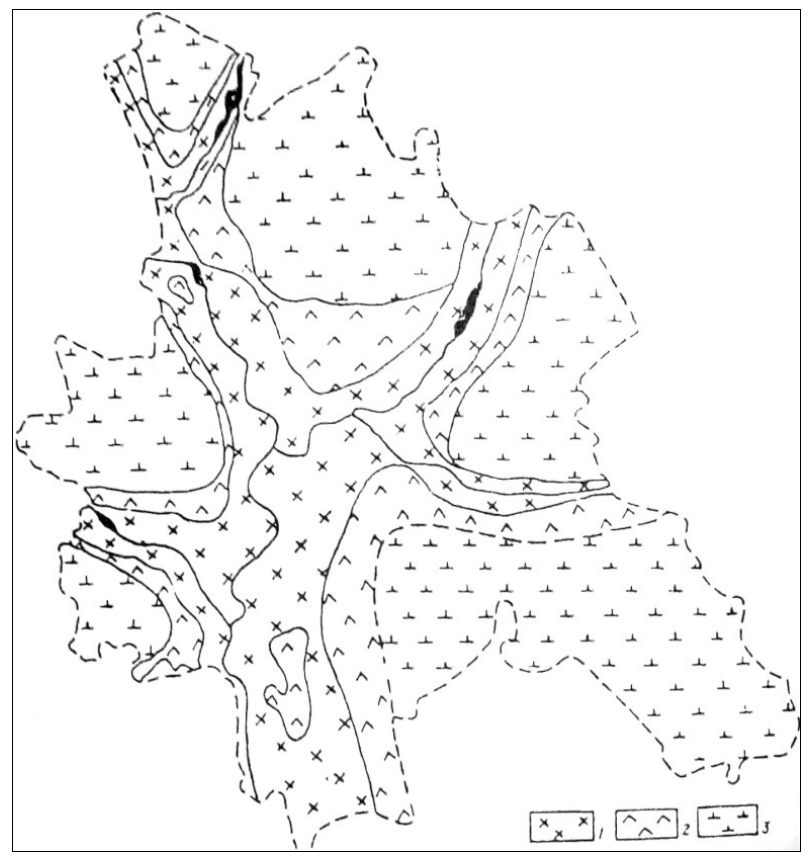

Fig. 2. Scheme of zoning of the territory

of Kharkiv under flood conditions: 1 - flooded territories; 2 - potentially unsinkable territories; 3 - potentially flooded territories (according to [20])

Factors of the formation of flooding processes and the cost

Table 2 of geotechnical surveys that determine these factors

\begin{tabular}{|c|c|c|c|c|c|c|}
\hline \multirow{2}{*}{ Flooding factors } & \multicolumn{6}{|c|}{ Study Area Number } \\
\hline & 1 & 2 & 3 & 4 & 5 & 6 \\
\hline Flooded area. $\mathrm{m}^{2}$ & 42000 & 2700 & 1500 & 28460 & 320000 & 3100 \\
\hline $\begin{array}{l}\text { The distance from the center } \\
\text { of the site to the natural basis } \\
\text { of drainage. } m\end{array}$ & 160 & 125 & 75 & 105 & 400 & 40 \\
\hline Filtration coefficient. $\mathrm{m} /$ day & 0.006 & 0.4 & 3.5 & 0.02 & 0.5 & 0.3 \\
\hline $\begin{array}{l}\text { Infiltration of precipitation. } \\
\mathrm{mm} / \text { year }\end{array}$ & 21924 & 1409 & 783 & 14856 & 16704 & 1618 \\
\hline $\begin{array}{l}\text { Leakage from communications. } \\
\mathrm{m}^{3} / \text { day }\end{array}$ & - & 2020 & 3232 & 2892 & 2829 & 3258 \\
\hline $\begin{array}{l}\text { The cost of geotechnical surveys } \\
\text { determining these factors. } \\
\text { thousand UAH }\end{array}$ & 7676.858 & 666.213 & 997.480 & 8982.718 & 23229.6 & 316.596 \\
\hline
\end{tabular}

To assess the most significant factors, we used a step-by-step regression method, in which the correlation coefficients between the resulting factors and separately selected factors were estimated. The analysis showed that the distance from the center of the site to the natural basis of drainage, infiltration of precipitation, and the area of the flooded site are the most significant factors.

\section{Research results}

Analysis of the actual cost of geotechnical surveys determining the factors of the formation of landslide processes with the cost of their implementation, calculated based on regression dependence. 
Denote the resulting factor by $\mathrm{Y}$, and independent factors by $x_{i}$, then linear regression can be written as follows:

$Y_{i}=A+B x_{i}+\varepsilon_{i}$, where $i=1,2, \ldots, n$.

Where

$\mathrm{Y}$ is the resulting factor,

$\mathrm{A}$ is the free term of model parameters,

$\mathrm{B}$ is the regression coefficient,

$\mathrm{x}_{\mathrm{i}}$ is independent factors,

is $\varepsilon_{i}$ is uncorrelated random variable errors.

In matrix recording, a sample multivariate regression model will look like this:

$$
\bar{Y}=B \cdot \bar{A},
$$

Where

$\bar{Y}=\left(y_{1}, y_{2} \ldots y_{n}\right)^{T}$ is transposed vector of the resulting factor;

$\bar{A}=\left(a_{0}, a_{1}, a_{2}, a_{3}\right)^{T}$ is a transposed vector of model parameters characterizing the displacement by $Y$;

$$
B=\left(\begin{array}{cccc}
1 & 1 & \ldots & 1 \\
x_{11} & x_{21} & \ldots & x_{n 1} \\
x_{12} & x_{22} & \ldots & x_{n 2} \\
x_{13} & x_{23} & \ldots & x_{n 3}
\end{array}\right)
$$

is regression coefficient (observation matrix), which characterizes the shift of the function graph by $X$.

In the regression analysis, hypotheses about the significance of the free term and the significance of the regression coefficient are checked (1). Thus, the task is to determine two hypotheses:

- The first hypothesis says that there is no linear relationship between the variables;

- The second hypothesis is that there is a linear relationship between the variables.

$$
\bar{Y}=(524711,62 \quad 924326,84 \quad 1935532,242
$$

To verify the proposed method of assessing the cost of geotechnical surveys based on these factors, the landslide site was selected on the Zhuravlev slopes of Kharkiv, in Studentska Street, where these engineering activities were carried out, and their actual value was determined.

Data for evaluation are presented in Table 3.

Table 3

Values of the factors of landslide process and the cost of geotechnical surveys determining these factors

\begin{tabular}{|l|c|}
\hline \multicolumn{1}{|c|}{ Independent factors } & Values \\
\hline $\mathrm{x}_{1}-$ the steepness of the slope, degrees & 16 \\
\hline $\mathrm{x}_{2}-$ groundwater level, $\mathrm{m}$ & 12 \\
\hline $\mathrm{x}_{3}-$ plasticity number & 0.11 \\
\hline $\begin{array}{l}\mathrm{Y}-\text { The cost of geotechnical surveys } \\
\text { determining these } \mathrm{x} \text { factors, thousand UAH }\end{array}$ & 1800 \\
\hline
\end{tabular}

In our case, the variables are the vector of model parameters (A) and the regression coefficient (B), which were used to forecast the cost of geotechnical surveys on a specific landslide site (2).

After a stepwise linear regression, three factors were selected where the linear relationship is more significant. As a result, the matrix of regression coefficients B and the vector $\bar{Y}$ have the form:

$$
B=\left(\begin{array}{cccc}
1 & 27 & 16 & 0,33 \\
1 & 25 & 11,02 & 0,13 \\
1 & 18 & 9 & 0,35 \\
1 & 12 & 11 & 0,22 \\
1 & 12,03 & 9,01 & 0,2201 \\
1 & 12,02 & 15 & 0,18
\end{array}\right), \bar{Y}=\left(\begin{array}{c}
762000 \\
750000 \\
1800000 \\
105000 \\
4000000 \\
2300000
\end{array}\right)
$$

Thus, to find unknown coefficients $a_{0}, a_{1}, a_{2}, a_{3}$ we obtain an overdetermined system of equations that we solve by the method of the least squares [21]. To do this, we multiply both sides of the vector-matrix equation (2) by the transposed matrix $\mathrm{B}^{\mathrm{T}}$ and get:

$$
B^{T} B \cdot \bar{A}=B^{T} \bar{Y}
$$

The matrix $\mathrm{B}^{\mathrm{T}} \mathrm{B}$ is square (with dimension 4 ), therefore $\bar{A}$ can be obtained from equation (3) as follows:

$$
\bar{A}=\left(B^{T} \cdot B\right)^{-1} \cdot B^{T} \bar{Y}
$$

As a result, a transposed vector of model parameters was obtained:

$$
\bar{A}=(3946793,571 \quad-88817,175 \quad-84511,088 \quad 994421,731)^{T} .
$$

Then, the values of the transposed vector of the resulting factor obtained using regression will be equal to:

$2170138,292335750,281 \quad 1790540,726)^{T}$.

In this case, the matrix of regression coefficients $(B)$ can be represented as a forecast vector $\left(x^{*}\right)$ :

$$
x^{*}=\left(\begin{array}{llll}
1 & 16 & 12 & 0.11
\end{array}\right) \text {. }
$$

Substituting the value of this vector (Table 5) into linear regression (1), we obtain a point forecast $\left(\mathrm{Y}^{*}\right)$ for the cost of landslide measures:

$$
\mathrm{Y}^{*}=\mathrm{A}_{\mathrm{i}} \mathrm{x}^{*}=a_{0}+a_{1} x_{1}^{*}+a_{2} x_{2}^{*}+a_{3} x_{3}^{*},
$$

Where $\mathrm{Y}^{*}$ is a point forecast; $\mathrm{a}_{0}, \mathrm{a}_{1}, \mathrm{a}_{2}, \mathrm{a}_{3}$ are the vectors of model parameters founded using the method of the least squares.

Thus, the theoretical estimated cost based on the proposed linear regression is:

$$
\mathrm{Y}^{*}=1620972.113 \mathrm{UAH} \text {. }
$$

The value of the real cost of the anti-landslide engineering measures for this site amounted to 1800000 UAH. 
Therefore, according to our calculations, the error in the obtained value $\left(\varepsilon_{\mathrm{i}}\right)$ is within the acceptable limits.

This allows us to conclude that it is possible to select the minimum volume of geotechnical surveys which will most likely evaluate the factors of landslide process occurrence and the cost of these surveys within the margin of error

Analysis of the real cost of geotechnical surveys determining the factors of formation of flooding processes, with the cost of their implementation, calculated based on regression dependence.

The studied method was tested based on the analysis of the dependence of the cost of geotechnical surveys to prevent flooding in Frontova Street on the identified flooding factors:

$x_{1}=4000$ is the site area, $\mathrm{m}^{2}$;

$x_{2}=70$ is the distance from the center of the site to the natural basis of drainage, $\mathrm{m}$;

$x_{3}=2088$ is precipitation infiltration, $\mathrm{mm} /$ year;

The actual cost of geotechnical surveys is 1423310 UAH.

In this case, the forecast vector will have the form:

$$
x^{*}=\left(\begin{array}{llll}
1 & 4000 & 70 & 2088
\end{array}\right)^{T} .
$$

Substituting the value of this vector into linear regression (5), we obtained a point forecast for the cost of engineering measures to combat flooding.

In our case, the theoretical estimated cost was: $\mathrm{Y}^{*}=1424400 \mathrm{UAH}$.

Thus, the error of the obtained value $\left(\varepsilon_{\mathrm{i}}\right)$ is within acceptable limits as for the study of landslide processes. This allows us to conclude that it is possible to select the minimum amount of geotechnical surveys, which will most likely evaluate the factors that cause the flooding process, as well as the cost of these surveys.

The determination coefficient $\left(R^{2}\right)$ was calculated by the formula to verify the adequacy of the regression model:

$$
R^{2}=\frac{\sum_{i}\left(\hat{Y}_{i}-\bar{Y}\right)^{2}}{\sum_{i}\left(Y_{i}-\bar{Y}\right)^{2}} .
$$

From this we obtain that the square of the correlation coefficient between the observed and the calculated values is equal to the fraction of variance, which shows the relationship of the model parameter vector $(A)$ and the regression coefficient $(B)$ in the linear regression model.

For the point forecast of landslide measures, the determination coefficient was $0.9438\left(R^{2}=0.9438\right)$, and for the point forecast of engineering measures to prevent flooding was $0.9804\left(R^{2}=0.9804\right)$.
The closer the coefficient is to 1 , the higher the quality of the regression. According to our calculations, both for landslide and flooding processes, the determination coefficients were in the range from 0.94 to 0.98 , which indicates a good quality of the regression.

\section{Discussion of the results}

The ranking of the factors that cause landslide processes, as well as the processes of flooding by the weight of the contribution to their origin and development, was carried out by constructing a linear regression dependence, which resulted in the selection of the most significant factors.

A set of techniques has been developed that allows us to analyze multifactor complex systems in the absence of the necessary material and time resources using a computer program complex designed for maintaining and documenting engineering calculations. Based on it, with a high degree of certainty, the principle of the choice of geotechnical surveys, which with a high degree of probability assess the factors of the occurrence of landslide and flooding processes is proposed; the possibility of identifying economic territories that may be subject to landslide and flooding processes based on the already existing basic data of previously performed geotechnical surveys it substantiated; a pre-design (planned) method of calculating the costs of geotechnical surveys based on the existing basic data is proposed.

The concept of this work allows predicting the level of risk of emergencies associated with landslide and flooding processes, the prospects of the use of economic territories.

\section{Conclusions}

1. A linear dependence of some geological (significant) factors responsible for landslide and flooding processes on the cost of geotechnical surveys determining these factors is proved.

2. The principle of the selection of geotechnical surveys, which assess the factors of the occurrence of landslide and flooding processes with high probability, has been developed.

3. The ability to identify economic territories that may be subject to landslides and floods was justified based on the existing basic data from previously performed geotechnical studies.

4. A pre-design (planned) method of calculating the costs of geotechnical surveys based on the existing basic data was proposed.

\section{References}

[1] Shneydmiller N.: Vseros.nauchnoy konfer. "Teoriya sovremennogo goroda: Proshloye, Nastoyashcheye, Budushcheye” Russia, Yekaterinburg 2016, 32. 
[2] Osipov V., Burova V., Zaikanov V., Minakova T.: Geoekolog. Inzhener. geologiya. Gidrogeolog., Geokriolog., 2015, 3, 195.

[3] Tiganova I.: Stroitel'stvo i obrazovaniye, 2012, 15.

[4] Zozulya P., Zozulya A.: Vestnik Univers. "Ekonomika: problemy, resheniya i perspektivy", 2015, 5, 63.

[5] Osipov V., Yeremina O., Kozlyakova I.: Geoekolog. Inzhener. geologiya., Gidrogeolog. Geokriolog., 2017, 3,3 .

[6] Say V.: Geodezíya, kartografíya í ayerofotoznímannya, 2011, 75, 127.

[7] Kuz'menko Ye., Zhuravel' O., Chepurna T., Chepurniy Í., Shtogrin L.: Geoínformatika, 2011, 3, 61.

[8] Keaton J.: Environmental and Engineering Geology, Encyclopedia of Life Systems, Support, 2010, 1,1.

[9] Tepel R.: AEG News, June, 2010, 53 (2), 32.

[10] Minayev V., Fadeyev A., Danilov R.: Problemy upravleniya riskami v tekhnosfere, 2010, 1 (13), 10.

[11] Natsíonal'na dopovíd' pro stan tekhnogen. ta prirod. bezpeki v Ukräní u 2014 r. , K.: DP “Agenstvo Chornobil' ínform”, 2015.

[12] Bondarik G., Pendin V., Yarg L.: Inzhenernaya geodinamika. KDU, Moskva 2015.
[13] Rud'ko G. and Osiyuka V.: Inzhenernya geodinamika Ukrainy i Moldovy (opolznevyye geosistemy). Bukrek, Chernovtsy 2012.

[14] Bileush A.: Opolzni i protivoopolznevyye meropriyatiya. Nauk. dumka, Kyiv 2009.

[15] Fengshan M., Li Zhanlu, Jie W., Kuo D.: Bullet. Engineer. Geology and the Environ. Offic. J. International Association for Engineer. Geology and the Environ., 2017, 3, 855.

[16] Pendin V. and Fomenko I.: Metodologiya otsenki i prognoza opolznevoy opasnosti. Lenand, Moskva 2015.

[17] Zarubina L.: Zashchita territoriy i stroitel'nykh ploshchadok ot podtopleniya gruntovymi vodami. Vologda: InfraInzheneriya, Moskva 2017.

[18] Kyoji S., Canuti P., Yueping Yin.: Landslide Science for a Safer Geoenvironment. Bücher: Springer Link, Springer, 2014.

[19] Barliani A.: Metody obrabotki i analiza prostranstvennykh i vremennykh dannykh. SGUGiT, Novosibirsk 2016.

[20] Strizhel'chik G., Sokolov Yu., Goldfeld I., et al.: Podtopleniye v naselennykh punktakh Khar'kov. obl. KH., Khar'kov 2003.

[21] Borovikov V.: Populyarnoye vvedeniye v sovremennyy analiz dannykh v sisteme STATISTICA. Goryachaya liniya-Telekom, Moskva 2013. 